\title{
Clinicopathological features and prognosis of mesenteric gastrointestinal stromal tumor: evaluation of a pooled case series
}

\author{
Fan Feng ${ }^{1, *}$, Bin Feng ${ }^{1, *}$, Shushang Liu ${ }^{1, *}$, Zhen Liu ${ }^{1}$, Guanghui $\mathbf{X u}^{1}$, Man Guo ${ }^{1}$, Xiao \\ Lian $^{1}$, Daiming Fan ${ }^{1}$ and Hongwei Zhang ${ }^{1}$ \\ ${ }^{1}$ Division of Digestive Surgery, Xijing Hospital of Digestive Diseases, Fourth Military Medical University, Xi'an, Shaanxi, China \\ * Fan Feng, Bin Feng and Shushang Liu have contributed equally to this work
}

Correspondence to: Hongwei Zhang, email: zhanghwfmmu@126.com

Keywords: gastrointestinal stromal tumor, mesentery, feature, prognosis

Received: August 29, $2016 \quad$ Accepted: January 16, $2017 \quad$ Published: January 28, 2017

Copyright: Feng et al. This is an open-access article distributed under the terms of the Creative Commons Attribution License 3.0 (CC BY 3.0), which permits unrestricted use, distribution, and reproduction in any medium, provided the original author and source are credited.

\section{ABSTRACT}

Background Due to the extremely rare incidence, data of clinicopathological features and prognosis of mesenteric gastrointestinal stromal tumors (GISTs) are limited. Therefore, the aim of the present study was to investigate the clinicopathological features and prognosis of mesenteric GISTs.

Patients and Methods Mesenteric GISTs cases were obtained from our center and from case reports and clinical series extracted from MEDLINE. Clinicopathological features and survivals were analyzed.

Results A total of 114 mesenteric GISTs were enrolled in present study. The most common symptom was abdominal pain $(20 / 72,27.8 \%)$, followed by abdominal mass $(13 / 72,18.1 \%)$ and distention $(9 / 72,12.5 \%)$. Most tumors exceeded $10 \mathrm{~cm}$ in diameter $(71 / 112,63.4 \%)$, exceeded 5/50HPF in mitotic index $(50 / 85,58.8 \%)$, and were high risk $(82 / 90,91.1 \%)$. The five-year disease free survival (DFS) and disease specific survival (DSS) was $57.7 \%$ and $60.1 \%$, respectively. Tumor size and mitotic index were associated with DFS and DSS. The distribution of tumor size, histological type, mitotic index and NIH risk category were significantly different between mesenteric and gastric GISTs. Prognosis of mesenteric GISTs was worse than that of gastric GISTs. However, multivariate analysis showed that location was not an independent prognostic factor for mesenteric and gastric GISTs.

Conclusions Most mesenteric GISTs exceeded $10 \mathrm{~cm}$ in diameter, exceeded 5/50HPF in mitotic index and were high risk. Mesenteric GISTs differed significantly from gastric GISTs in respect to clinicopathologic features. Mitotic index and tumor size were prognostic factors for mesenteric GISTs. The prognosis were comparable between mesenteric and gastric GISTs.

\section{INTRODUCTION}

Gastrointestinal stromal tumors (GISTs) are the commonest mesenchymal neoplasms of the gastrointestinal (GI) tract and represent $1-2 \%$ of all GI malignancies [1]. GISTs are considered to arise from the interstitial cells of Cajal (ICC) [2]. Most GISTs displayed spindle cell morphology (70\%), followed by epithelioid (20\%) and mixed phenotypes (10\%) [3]. GISTs can occur anywhere throughout the GI tract and are seen most commonly in the stomach (40 to $70 \%$ ) and small intestine (20 to $40 \%$ ) [4]. GISTs that arise outside the GI tract as primary tumor are designated as extra-GISTs (EGISTs). EGISTs are located in the omentum, mesentery, liver, pancreas and retroperitoneum, etc [5].

Due to the extremely rare incidence, reporting of mesenteric GISTs has been limited to individual case reports and case series of small numbers. Studies involving large numbers of mesenteric GISTs are lacking. Thus, several questions remain unanswered, including clinical 
Table 1: Clinicopathological characteristics of 114 cases of mesenteric GISTs

\begin{tabular}{|c|c|}
\hline Characteristics & Parameters \\
\hline \multicolumn{2}{|l|}{ Age $\left(\sum=113\right)$} \\
\hline$\leq 60$ & $68(60.2 \%)$ \\
\hline$>60$ & $45(39.8 \%)$ \\
\hline \multicolumn{2}{|l|}{ Gender $\left(\sum=102\right)$} \\
\hline Male & $52(51.0 \%)$ \\
\hline Female & $50(49.0 \%)$ \\
\hline \multicolumn{2}{|l|}{ Accompanied tumor $\left(\sum=44\right)$} \\
\hline GISTs with other locations & $12(27.3 \%)$ \\
\hline Other type of tumors & $2(4.5 \%)$ \\
\hline \multicolumn{2}{|l|}{ Symptoms $\left(\sum=72\right)$} \\
\hline Abdominal pain & $20(27.8 \%)$ \\
\hline Abdominal mass & $13(18.1 \%)$ \\
\hline Abdominal distension & $9(12.5 \%)$ \\
\hline \multicolumn{2}{|l|}{ Tumor size $\left(\sum=112\right)$} \\
\hline$\leq 2 \mathrm{~cm}$ & $1(0.9 \%)$ \\
\hline $2.1-5 \mathrm{~cm}$ & $14(12.5 \%)$ \\
\hline $5.1-10 \mathrm{~cm}$ & $26(23.2 \%)$ \\
\hline$>10 \mathrm{~cm}$ & $71(63.4 \%)$ \\
\hline \multicolumn{2}{|l|}{ Imaging features $\left(\sum=28\right)$} \\
\hline Solid & $12(42.9 \%)$ \\
\hline Cystic & $3(10.7 \%)$ \\
\hline Mixed & $13(46.4 \%)$ \\
\hline \multicolumn{2}{|l|}{ Surgical resection $\left(\sum=111\right)$} \\
\hline Complete resection & $101(91.0 \%)$ \\
\hline Incomplete resection & $3(2.7 \%)$ \\
\hline No surgery & $7(6.3 \%)$ \\
\hline \multicolumn{2}{|l|}{ Histological type $\left(\sum=90\right)$} \\
\hline Spindle & $66(73.3 \%)$ \\
\hline Epithelioid & $13(14.5 \%)$ \\
\hline Mixed & $11(12.2 \%)$ \\
\hline \multicolumn{2}{|l|}{ Mitotic index $\left(\sum=85\right)$} \\
\hline$\leq 5$ & $35(41.2 \%)$ \\
\hline$>5$ & $50(58.8 \%)$ \\
\hline \multicolumn{2}{|l|}{ Immunohistochemisty } \\
\hline $\mathrm{CD} 117\left(\sum=50\right)$ & $46(92.0 \%)$ \\
\hline DOG-1 $\left(\sum=11\right)$ & $10(91.0 \%)$ \\
\hline \multicolumn{2}{|l|}{ Mutational status $\left(\sum=18\right)$} \\
\hline KIT & $5(27.8 \%)$ \\
\hline PDGFRA & $7(38.9 \%)$ \\
\hline Wild type & $6(33.3 \%)$ \\
\hline \multicolumn{2}{|l|}{ NIH risk category $\left(\sum=90\right)$} \\
\hline Very low risk & $1(1.1 \%)$ \\
\hline Low risk & $7(7.8 \%)$ \\
\hline Intermediate risk & 0 \\
\hline High risk & $82(91.1 \%)$ \\
\hline \multicolumn{2}{|l|}{ Adjuvant therapy $\left(\sum=41\right)$} \\
\hline Yes & $25(61.0 \%)$ \\
\hline No & $16(39.0 \%)$ \\
\hline
\end{tabular}

GIST: gastrointestinal stromal tumor; DOG-1: discovered on GIST 1; KIT: c-kit proto-oncogene; NIH: National Institutes of Health; 
Table 2: Survival data of 57 cases of mesenteric GISTs

\begin{tabular}{|c|c|}
\hline \multicolumn{1}{|c|}{ Survival characteristics } & Parameter \\
\hline Follow up time & \\
\hline Mean $(\mathrm{m}, \pm \mathrm{SD})$ & $47.7 \pm 48.6$ \\
\hline Median(m, range) & $27(2,192)$ \\
\hline Survival data & 26 \\
\hline Recurrence or metastasis & 18 \\
\hline GISTs related deaths & \\
\hline Survival rates (\%) & $84.3 / 63.0 / 57.7$ \\
\hline 1-/3-/5-year DFS & $92.3 / 67.5 / 60.1$ \\
\hline $1-/ 3-/ 5-y e a r ~ D S S$ &
\end{tabular}

SD: Standard deviation;

DFS: disease-free survival;

DSS: disease-specific survival.

and pathological characteristics and prognosis. Therefore, the aim of the present study was to investigate the clinicopathological features and prognosis of mesenteric GISTs.

\section{RESULTS}

The clinicopathological features were summarized in Table 1 . There were 52 male $(51.0 \%)$ and 50 female $(49.0 \%)$. The median age was $57(6-84)$ years. The most common symptom was abdominal pain (20/72, 27.8\%), followed by abdominal mass $(13 / 72,18.1 \%)$ and abdominal distension $(9 / 72,12.5 \%)$. One hundred and one patients underwent complete surgical resection $(101 / 111$, $91.0 \%), 3$ patients underwent palliative resection $(3 / 111$, $2.7 \%)$, and 7 patients did not receive surgery $(7 / 111$, $6.3 \%)$.
The tumors ranged from 0.4 to $39 \mathrm{~cm}$ (median, 12.0 $\mathrm{cm}$; mean, $13.7 \mathrm{~cm}$ ). Sixty-six patients displayed spindle cell morphology $(66 / 90,73.3 \%), 13$ patients displayed epithelioid morphology $(13 / 90,14.5 \%)$ and 11 patients displayed mixed morphology $(11 / 90,12.2 \%)$. The mitotic index of 50 patients exceeded 5/50 HPF (50/85, 58.8\%). CD117 positivity was detected in 46 patients $(46 / 50$, $92.0 \%)$, DOG-1 positivity was detected in 10 patients $(10 / 11,91.0 \%)$. Eighteen patients were analyzed for gene mutation status. Five patients carrying KIT mutation (5/18, 27.8\%), 7 patients carrying PDGFRA mutation $(7 / 18,38.9 \%)$, the remaining 6 patients were wild type $(6 / 18,33.3 \%)$. According to NIH risk classification, 1 patient was very low risk $(1 / 90,1.1 \%), 7$ patients were low risk $(7 / 90,7.8 \%)$, no patient was intermediate risk, 82 patients were high risk $(82 / 90,91.1 \%)$. Information of imatinib therapy were recorded in 41 patients, and 25 patients $(61.0 \%)$ received imatinib therapy.

Survival data of 57 patients were eventually selected for analysis (Table 2). The follow up time ranged from 2 to 192 months (mean, 47.7 months; median, 27.0 months). Twenty-six patients showed recurrence or metastasis, 18 patients suffered from GIST related deaths. The 1-, 3- and 5-year DFS was $84.3 \%, 63.0 \%$ and $57.7 \%$, respectively. The 1-, 3- and 5-year DSS was $92.3 \%, 67.5 \%$ and $60.1 \%$, respectively. The DFS and DSS of mesenteric GISTs were shown in Figure 2.

Prognostic factors for DFS and DSS of mesenteric GISTs were shown in Table 3. Univariate analysis showed that tumor size and mitotic index were prognostic factors for mesenteric GISTs. However, multivariate analysis showed that tumor size was the only independent risk

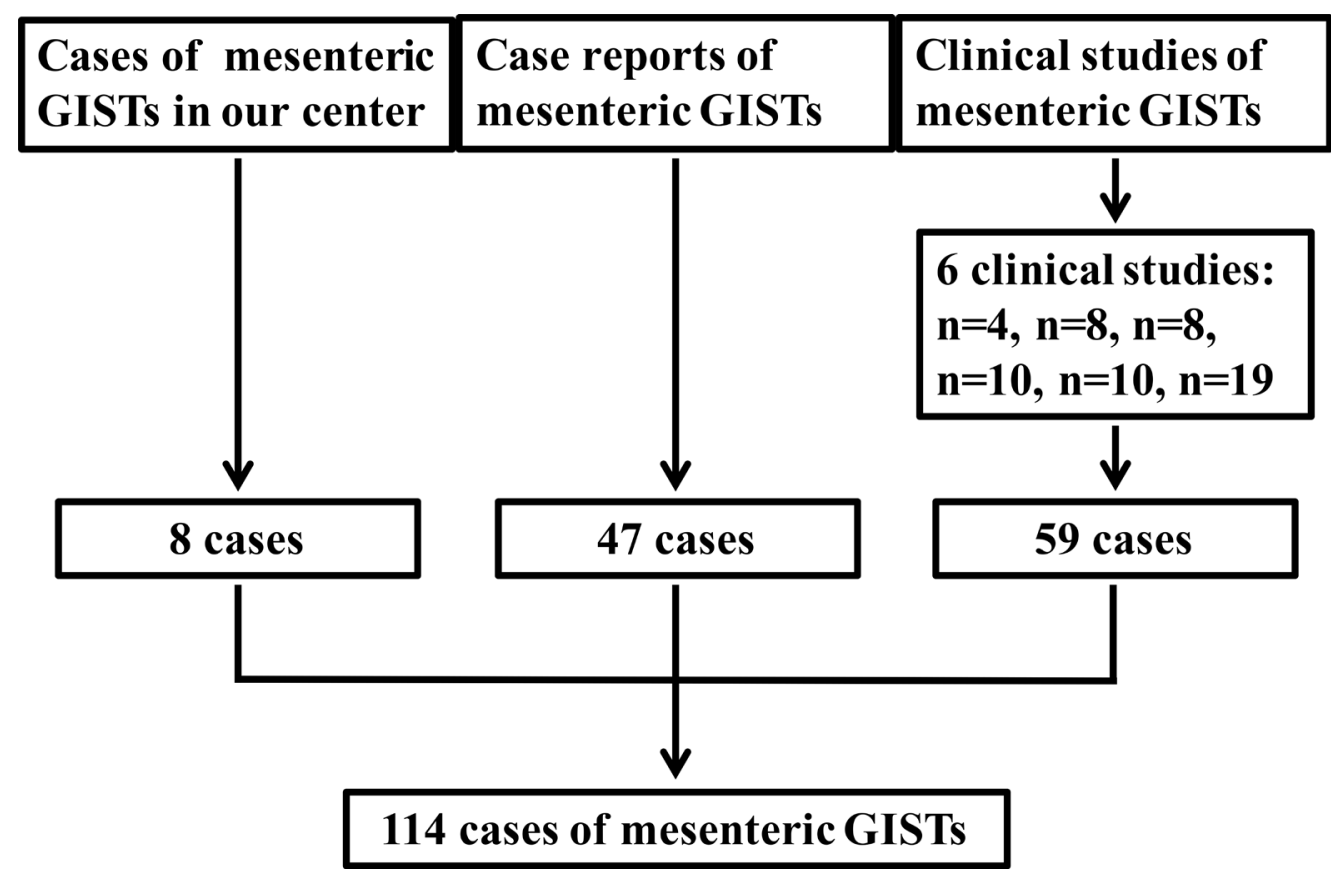

Figure 1: Schematic diagram regarding selection of mesenteric GISTs. 
Table 3: Prognostic factors for DFS and DSS in patients with mesenteric GISTs according to univariate and multivariate analysis $(n=57)$

\begin{tabular}{|l|c|c|c|c|c|c|}
\hline \multicolumn{1}{|c|}{ Prognostic factors } & $\boldsymbol{\beta}$ & Univariate analysis & \multicolumn{3}{c|}{ Multivariate analysis } \\
\hline DFS & & & $\boldsymbol{P}$ Hazard ratio (95\% CI) & $\boldsymbol{P}$ value \\
\hline Tumor size $(\leq 10 />10)$ & 2.178 & $\begin{array}{c}8.825 \\
(1.138-68.438)\end{array}$ & 0.037 & & & \\
\hline Mitotic index $(\leq 5 />5)$ & 1.661 & $\begin{array}{c}5.263 \\
(1.398-19.804)\end{array}$ & 0.014 & 1.216 & $\begin{array}{c}3.374 \\
(0.864-13.181)\end{array}$ & 0.080 \\
\hline NIH risk category $(1,2,3 / 4)$ & 1.740 & $\begin{array}{c}5.700 \\
(0.388-83.746)\end{array}$ & 0.204 & & & \\
\hline DSS & & & & & 8.197 \\
\hline Tumor size $(\leq 10 />10)$ & 1.587 & $\begin{array}{c}4.888 \\
(1.108-21.566)\end{array}$ & 0.036 & 2.104 & & 0.046 \\
\hline Mitotic index $(\leq 5 />5)$ & 1.358 & $\begin{array}{c}3.890 \\
(1.248-12.128)\end{array}$ & 0.019 & & & \\
\hline NIH risk category $(1,2,3 / 4)$ & 3.541 & $\begin{array}{c}31.543 \\
(0.160-6199.591)\end{array}$ & 0.200 & & & \\
\hline
\end{tabular}

DFS: disease-free survival;

DSS: disease-specific survival;

NIH: National Institutes of Health.

CI: Confidence interval.

Table 4: Comparison of selected clinicopathological parameters between mesenteric and gastric GISTs.

\begin{tabular}{|c|c|c|c|}
\hline Characteristics & Mesentery $(\boldsymbol{n}=\mathbf{1 1 4})$ & Stomach $(\boldsymbol{n}=\mathbf{2 9 7})$ & $\boldsymbol{P}$ value \\
\hline Age & & & \\
\hline$\leq 60$ & 68 & 168 & 0.576 \\
\hline$>60$ & 45 & 129 & \\
\hline Gender & 52 & & \\
\hline Male & 50 & 155 & 0.907 \\
\hline Female & & 142 & \\
\hline Tumor size & 1 & 96 & $<0.001$ \\
\hline$\leq 2 \mathrm{~cm}$ & 14 & 107 & \\
\hline $2.1-5 \mathrm{~cm}$ & 26 & 72 & \\
\hline $5.1-10 \mathrm{~cm}$ & 71 & 22 & \\
\hline$>10 \mathrm{~cm}$ & & & \\
\hline Histological type & 66 & 375 & $<0.001$ \\
\hline Spindle & 13 & 19 & \\
\hline Epithelioid & 11 & & \\
\hline Mixed & & 163 & 0.027 \\
\hline Mitotic index & 35 & 134 & \\
\hline$\leq 5$ & 50 & 83 & $<0.001$ \\
\hline$>5$ & & 58 & \\
\hline NIH risk category & 1 & & \\
\hline Very low & 7 & & \\
\hline Low & 0 & & \\
\hline Intermediate & & & \\
\hline High & & & \\
\hline
\end{tabular}

NIH: National Institutes of Health.

factor for DSS. The DFS and DSS of mesenteric GISTs according to tumor size and mitotic index were shown in Figure 3 and 4.

The clinicopathological features of 114 mesenteric GISTs including age, gender, tumor size, histological type, mitotic index and NIH risk category were compared with 297 gastric GISTs in our institution (Table 4). The results showed that the distribution of tumor size, histological type, mitotic index and NIH risk category were significantly different between mesenteric and gastric GISTs (all $P<0.05$ ).

In order to compare the prognosis of mesenteric GISTs with gastric GISTs, 57 cases of mesenteric GISTs and 217 cases of gastric GISTs with follow up data were analyzed. The results showed that DFS and DSS of mesenteric GISTs were significantly lower than that of gastric GISTs (Figure 5). Further, multivariate analysis was performed to evaluate the prognostic value 

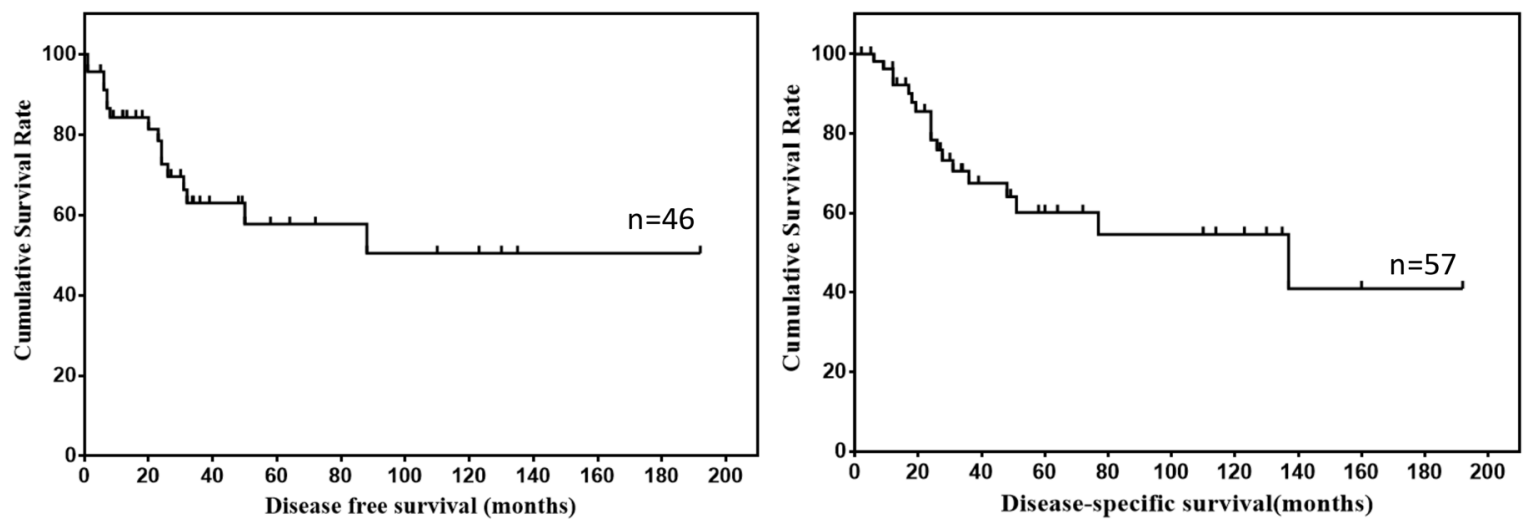

Figure 2: DFS and DSS of mesenteric GISTs.
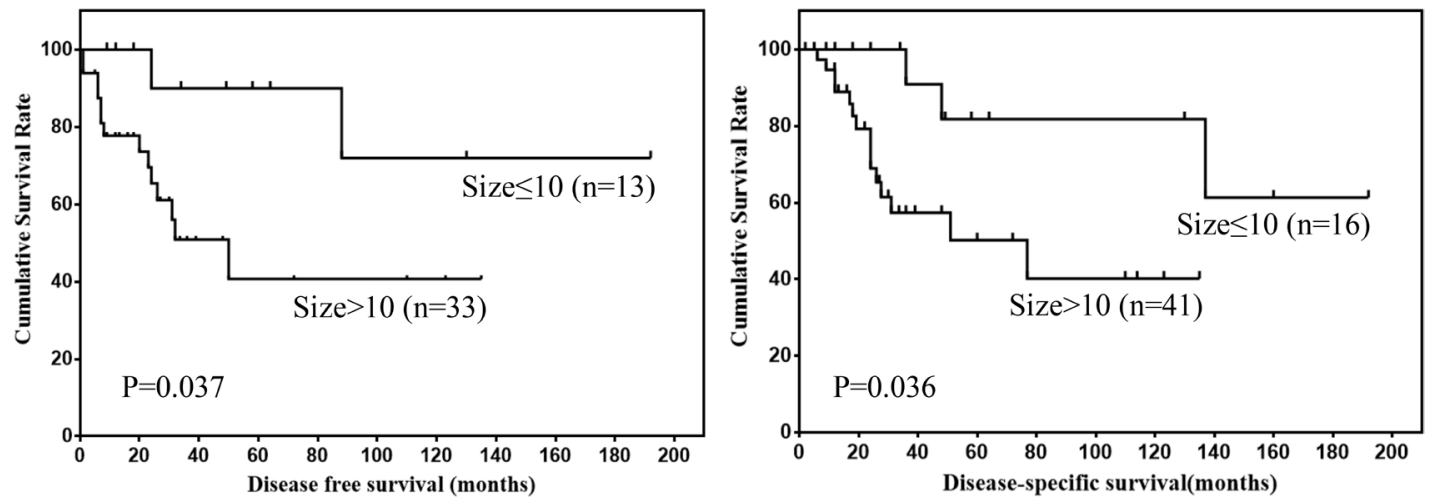

Figure 3: DFS and DSS of mesenteric GISTs by tumor size.
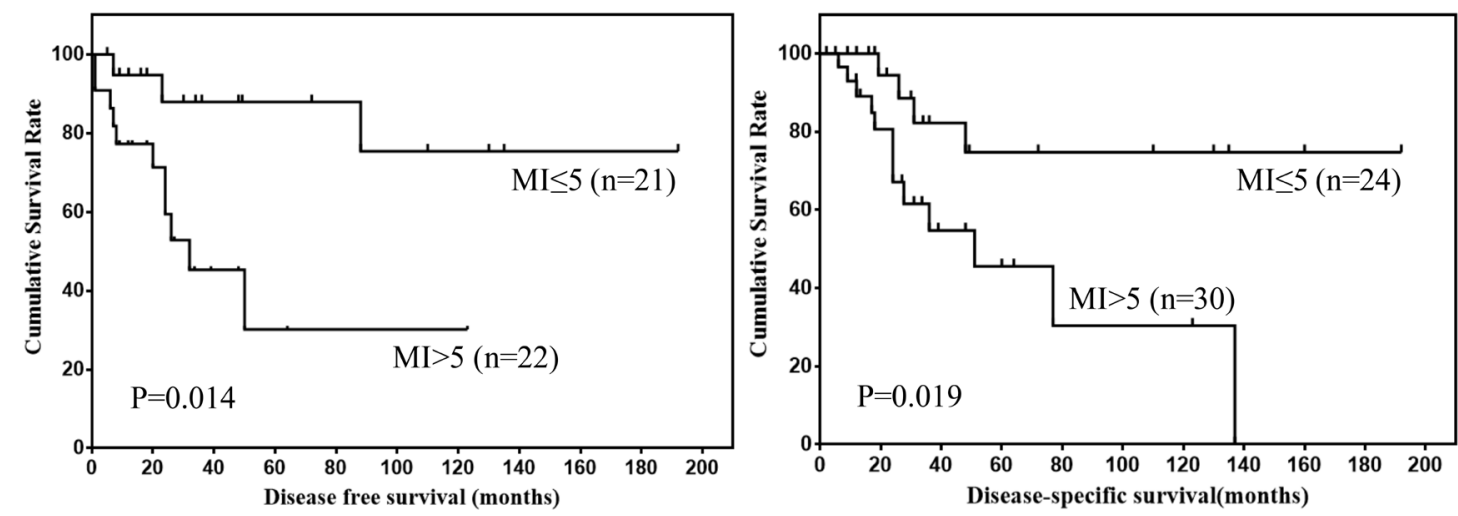

Figure 4: DFS and DSS of mesenteric GISTs by mitotic index.
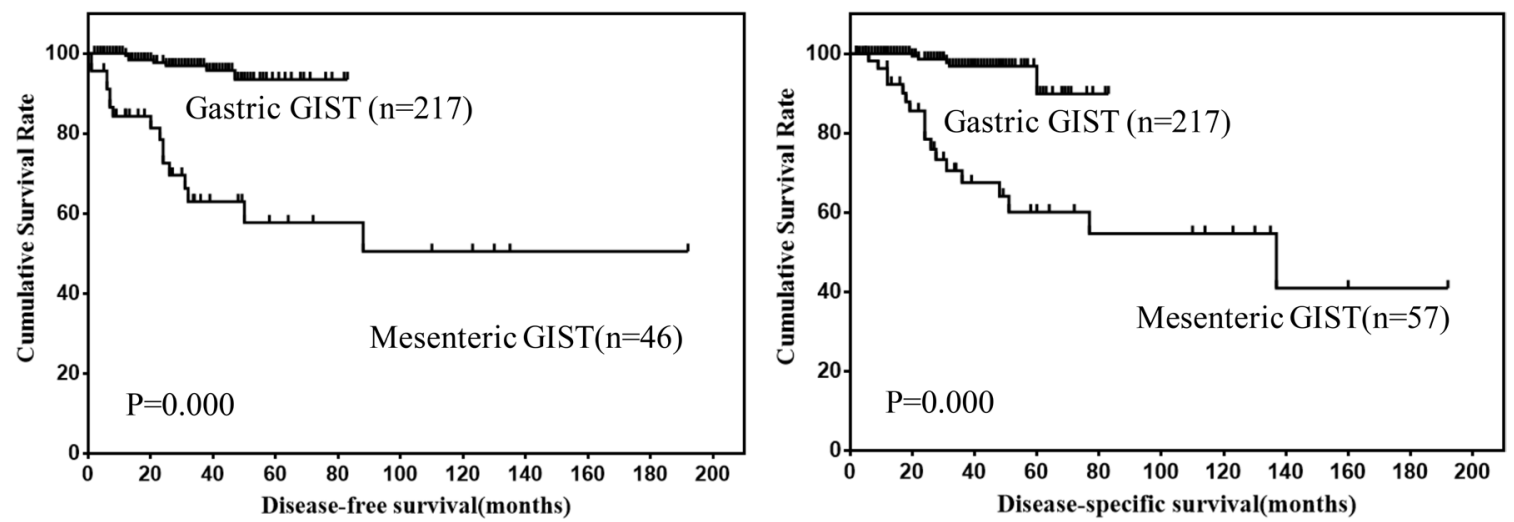

Figure 5: Comparison of DFS and DSS between mesenteric and gastric GISTs. 
Table 5: Comparative survival analysis of mesenteric and gastric GISTs using univariate and multivariate analysis.

\begin{tabular}{|c|c|c|c|c|c|c|c|c|}
\hline \multirow{2}{*}{ Survival } & \multirow{2}{*}{$\frac{\text { Mesentery }}{(n=57)}$} & \multirow{2}{*}{$\begin{array}{l}\text { Stomach } \\
(n=217)\end{array}$} & \multicolumn{3}{|c|}{ Univariate analysis } & \multicolumn{3}{|c|}{ Multivariate analysis } \\
\hline & & & $\bar{\beta}$ & HR $(95 \%$ CI) & $P$ & $\bar{\beta}$ & HR $(95 \%$ CI) & $P$ \\
\hline \multicolumn{9}{|l|}{ DFS } \\
\hline 1-year & 84.3 & 99.5 & 2.331 & $\begin{array}{c}10.293 \\
(4.184-25.320)\end{array}$ & 0.000 & 0.702 & $\begin{array}{c}2.018 \\
(0.474-8.581)\end{array}$ & 0.342 \\
\hline 3-year & 63.0 & 96.9 & & & & & & \\
\hline 5-year & 57.7 & 93.5 & & & & & & \\
\hline \multicolumn{9}{|l|}{ DSS } \\
\hline 1-year & 92.3 & 100.0 & 2.438 & $\begin{array}{c}11.451 \\
(4.174-31.417)\end{array}$ & 0.000 & 0.723 & $\begin{array}{c}2.060 \\
(0.542-7.822)\end{array}$ & 0.289 \\
\hline 3-year & 67.5 & 96.8 & & & & & & \\
\hline 5-year & 60.1 & 89.9 & & & & & & \\
\hline
\end{tabular}

DFS: disease-free survival;

DSS: disease-specific survival;

CI: confidence interval;

HR: hazard ratio.

of locations (Table 5). However, the results showed that location was not an independent risk factor for prognosis of mesenteric and gastric GISTs (both $P>0.05$ ).

\section{DISCUSSION}

Due to the extremely rare incidence, studies involving large numbers of mesenteric GISTs are lacking. Therefore, the aim of the present study was to investigate the clinicopathological features and prognosis of mesenteric GISTs. The present study represents the largest analysis of mesenteric GISTs.

The precise etiology of mesenteric GISTs remains to be clarified. Some investigators have proposed that EGISTs are mural tumors with extensive extramural growth resulting in eventual loss of connection with gut wall [6]. However, this hypothesis lacks evidence. On the other hand, other researchers have proposed that GISTs may arise from a common precursor cell of ICC and smooth muscle cell, which may account for their growth from and outside the GI tract [7]. Terada et al. have demonstrated the existence of scattered KIT-positive ICC like cells in surface of the normal mesocolon [8]. This further provide evidence for the hypothesis that EGISTs may arise from precursor cell of ICC outside the GI tract. However, the existence of ICC like cells in the mesostenium have not been identified.

The spectrum of clinical presentation of GISTs is broad and depends on tumor location and tumor size. For mesenteric GISTs, tumors appear to have enough space to grow and may present clinical symptoms after a significant period of time with a considerable tumor size. In our present study, most tumors exceeded $10 \mathrm{~cm}$ in diameter. Thus, early diagnosis of mesenteric GISTs is very difficult. Once mesenteric GISTs reached a significant size, symptoms will appear. In our present study, the most common symptoms include abdominal pain, mass and distension.
Even with R0 resection, there is a high risk of recurrence and distant metastasis. However, no mention of mesenteric GISTs specific recurrence or metastasis was made previously. In our present study, half of patients with tumor progression after R0 resection suffered from abdominal recurrence. For distant metastasis, the most common site was liver. Metastasis to lung and brain was also occasionally found.

In 1998, Hirota et al. reported their groundbreaking discovery of KIT mutations in GISTs. It is now established that $70 \%$ to $80 \%$ of GISTs harbor KIT mutation [9], and PDGFRA mutation occur in approximately $8 \%$ to $10 \%$ of GISTs [10]. In our present study, gene mutations were recorded in only eighteen patients. Among them, 7 patients (38.9\%) carrying PDGFRA mutation. The incidence of PDGFRA mutation in our present study was relatively higher than previous report. This indicated that the incidence of KIT and PDGFRA gene mutation could be various from each other depend on the location of GISTs. However, the association between the tumor location and gene mutation status needs further investigation.

In our present study, most tumors exceeded 10 $\mathrm{cm}$ in diameter and almost all the tumors were high risk. Therefore, the existing classification criteria which defined by a combination of mitotic index and tumor size may not be applicable to mesenteric GISTs. Reith et al. reported that high cellularity, mitotic index exceeds $2 / 50$ $\mathrm{HPF}$ and presence of necrosis were factors indicative of a potentially aggressive clinical course for EGIST [11]. However, the relatively short follow up period in the study may result in bias of the data. Thus, a more appropriate grading system may be needed for the classification of EGISTs.

Tumor location is also one prognostic factor for GISTs [12], and it was considered that EGISTs were more aggressive than gastric GISTs. However, the modified NIH risk classification distinguishes only gastric from non-gastric GISTs, and the prognosis of mesenteric GISTs 
are not discussed. Thus, the prognosis of mesenteric and gastric GISTs were compared. We found that the prognosis of mesenteric GISTs was significantly worse than that of gastric GISTs. However, multivariate analysis showed that tumor location was not an independent risk factor for prognosis of mesenteric and gastric GISTs. We considered that the poor prognosis of mesenteric GISTs was mainly attributed to the larger tumor size and higher mitotic index, not to location.

There were a few limitations in our present study. Firstly, the present study is a retrospective analysis and the completeness of data is limited. Secondly, the sample size was not large enough, which will result in statistical bias. Thirdly, the clinicopathological features and prognosis of mesenteric GISTs were not compared with EGISTs in other locations.

\section{CONCLUSIONS}

Most mesenteric GISTs exceeded $10 \mathrm{~cm}$ in diameter, exceeded 5/50HPF in mitotic index and were high risk. Mesenteric GISTs differ significantly from gastric GISTs in respect to clinicopathologic features. Mitotic index and tumor size were risk factors for prognosis of mesenteric GISTs. The prognosis were comparable between mesenteric and gastric GISTs.

\section{PATIENTS AND METHODS}

GISTs cases of the mesentery were from our institution and literature. From May 2010 to March 2015, 8 cases of mesenteric GISTs were diagnosed and treated in our institution. Literature search of MEDLINE was performed for all articles in English published from 1999 through 2015. MEDLINE search resulted in 36 case reports $[7,8,13-46]$ including 47 cases and 6 case series [47-52] including 59 cases. As a result, a total of 114 mesenteric GISTs patients were identified (Figure 1). In addition, the clinicopathological characteristics of 297 patients of gastric GISTs in our center were analyzed and compared with mesenteric GISTs. Among them, the prognosis of 217 gastric GISTs patients with followup data were analyzed and compared with mesenteric GISTs. This study was approved by the Ethics Committee of Xijing Hospital, and written informed consent was obtained from the eight patients in our center.

Data including age, gender, accompanied tumor, symptoms, tumor size, imaging features, surgical intervention, histological type, immunohistochemical features, mutational status, mitotic index, NIH risk category, adjuvant therapy, tumor progression and survival data were recorded. The tumors were categorized into very low, low, intermediate and high risk groups according to the modified NIH risk classification criteria [53]. For survival analysis, the inclusion criteria were listed as follows: 1. without distant metastasis, 2. without GISTs in other locations, 3. R0 resection, 4. without other malignant tumors, 5. without neoadjuvant imatinib therapy, 6. with follow up data. Due to data acquisition, completeness of data is limited.

Data were processed using SPSS 22.0 for Windows (SPSS Inc., Chicago, IL, USA). Discrete variables were analyzed using the Chi-square test or Fisher's exact test. Numerical variables were expressed as the mean \pm SD unless. Significant predictors for prognosis identified by univariate analysis were further assessed by multivariate analysis using Cox's proportional hazards regression model was employed for multivariate analysis. Evaluation of disease-free-survival (DFS) and disease-specificsurvival (DSS) were obtained by the Kaplan-Meier method. DFS was defined as the length of time from the date of surgery to the date of recurrence. DSS was defined as the length of time from the date of surgery to the date of cancer associated death. The $\mathrm{P}$ value was considered to be statistically significant at the $5 \%$ level.

\section{Abbreviations}

GIST: Gastrointestinal stromal tumor; HPF: High power field; DFS: Disease-free survival; DSS: Diseasespecific survival; NIH: National Institutes of Health; GI: Gastrointestinal; ICC: Interstitial cells of Cajal; EGIST: Extra-gastrointestinal stromal tumor; DOG-1: Discovered on GIST 1; KIT: c-kit proto-oncogene protein; SD: Standard deviation; CI: Confidence interval; HR: Hazard ratio.

\section{ACKNOWLEDGMENTS}

This study was supported in part by grants from the National Natural Scientific Foundation of China [NO. 31100643, 31570907, 81572306, 81502403, XJZT12Z03].

\section{CONFLICTS OF INTEREST}

There are no financial or other relations that could lead to a conflict of interest.

\section{REFERENCES}

1. Joensuu H, Hohenberger P, Corless CL. Gastrointestinal stromal tumour. Lancet. 2013; 382:973-983.

2. Feng F, Liu Z, Zhang X, Guo M, Xu G, Ren G, Hong L, Sun L, Yang J, Zhang H. Comparison of Endoscopic and Open Resection for Small Gastric Gastrointestinal Stromal Tumor. Transl Oncol. 2015; 8:504-508.

3. Yang J, Feng F, Li M, Sun L, Hong L, Cai L, Wang W, $\mathrm{Xu} \mathrm{G}$, Zhang H. Surgical resection should be taken into consideration for the treatment of small gastric gastrointestinal stromal tumors. World J Surg Oncol. 2013; 11:273. 
4. Feng F, Tian Y, Liu Z, Xu G, Liu S, Guo M, Lian X, Fan D, Zhang H. Clinicopathologic Features and Clinical Outcomes of Esophageal Gastrointestinal Stromal Tumor: Evaluation of a Pooled Case Series. Medicine (Baltimore). 2016; $95: \mathrm{e} 2446$.

5. Joensuu H, Vehtari A, Riihimaki J, Nishida T, Steigen SE, Brabec P, Plank L, Nilsson B, Cirilli C, Braconi C, Bordoni A, Magnusson MK, Linke Z, et al. Risk of recurrence of gastrointestinal stromal tumour after surgery: an analysis of pooled population-based cohorts. Lancet Oncol. 2012; 13:265-274.

6. Agaimy A, Wunsch PH. Gastrointestinal stromal tumours: a regular origin in the muscularis propria, but an extremely diverse gross presentation. A review of 200 cases to critically re-evaluate the concept of so-called extragastrointestinal stromal tumours. Langenbecks Arch Surg. 2006; 391:322-329.

7. Goh BK, Chow PK, Kesavan SM, Yap WM, Chung YF, Wong WK. A single-institution experience with eight CD117-positive primary extragastrointestinal stromal tumors: critical appraisal and a comparison with their gastrointestinal counterparts. J Gastrointest Surg. 2009; 13:1094-1098.

8. Terada T. Primary extragastrointestinal stromal tumor of the transverse mesocolon without c-kit mutations but with PDGFRA mutations. Med Oncol. 2009; 26:233-237.

9. Corless CL, Barnett CM, Heinrich MC. Gastrointestinal stromal tumours: origin and molecular oncology. Nat Rev Cancer. 2011; 11:865-878.

10. Heinrich MC, Corless CL, Duensing A, McGreevey L, Chen CJ, Joseph N, Singer S, Griffith DJ, Haley A, Town A, Demetri GD, Fletcher CD, Fletcher JA. PDGFRA activating mutations in gastrointestinal stromal tumors. Science. 2003; 299:708-710.

11. Reith JD, Goldblum JR, Lyles RH, Weiss SW. Extragastrointestinal (soft tissue) stromal tumors: an analysis of 48 cases with emphasis on histologic predictors of outcome. Mod Pathol. 2000; 13:577-585.

12. Rutkowski P, Nowecki ZI, Michej W, Debiec-Rychter M, Wozniak A, Limon J, Siedlecki J, Grzesiakowska U, Kakol M, Osuch C, Polkowski M, Gluszek S, Zurawski Z, Ruka W. Risk criteria and prognostic factors for predicting recurrences after resection of primary gastrointestinal stromal tumor. Ann Surg Oncol. 2007; 14:2018-2027.

13. Li W, Cui Y, Ren G, Wang J, Wu X. Extragastrointestinal stromal tumor of the mesoappendix: CT findings and a review of the literature. World J Surg Oncol. 2012; 10:211.

14. Puljiz M, Alvir I, Danolic D, Tomica D, Mamic I, Puljiz Z, Zorica R, Balja MP. Primary extragastrointestinal stromal tumor of the sigmoid mesocolon with metastatic spread to greater omentum: case report. Coll Antropol. 2013; 37:625627.

15. Kolarik J, Drapela J. [Extragastrointestinal stromal tumor (EGIST)-a case review]. [Article in Czech]. Rozhl Chir.
2012; 91:241-245.

16. Ferrocci G, Rossi C, Bolzon S, Della CL, Tartarini D, Zanzi F, Durante E, Azzena G. Gastrointestinal stromal tumours. Our experience ten years later. Ann Ital Chir. 2011; 82:267272.

17. Park SH, Kim MK, Kim H, Song BJ, Chi JG. Ultrastructural studies of gastrointestinal stromal tumors. J Korean Med Sci. 2004; 19:234-244.

18. $\mathrm{Xu} \mathrm{L}$, Wen G, Ding Y, Zhao L. A lethal mesenteric gastrointestinal stromal tumor: a case report and review of the literature. Int J Clin Exp Pathol. 2015; 8:11715-11721.

19. Kirby R, Rajasagaram N, Ghusn M. Primary mesenteric gastrointestinal stromal tumour. J Surg Case Rep. 2014; 2014.

20. Muto M, Fujiya M, Okada T, Inoue M, Yabuki H, Kohgo Y. An invasive extragastrointestinal stromal tumor curably resected following imatinib treatment. J Gastrointestin Liver Dis. 2013; 22:329-332.

21. Patnayak R, Jena A, Parthasarathy S, Prasad PD, Reddy MK, Chowhan AK, Rukamangadha N, Phaneendra BV. Primary extragastrointestinal stromal tumors: a clinicopathological and immunohistochemical study - a tertiary care center experience. Indian J Cancer. 2013; 50:41-45.

22. Xue D, Chen H, Chen Y. Giant extragastrointestinal stromal tumor in the transverse mesocolon concomitant with gastric cancer in an elderly patient: Case report. Oncol Lett. 2013; 5:627-630

23. Tulinsky L, Dostalik J, Dvorackova J, Tomanova R. [A giant gastrointestinal stromal tumour - a case report]. [Article in Czech]. Rozhl Chir. 2012; 91:486-489.

24. Samlani-Sebbane Z, Diffaa A, Krati K, Finech A, Rabbani K, Narjis Y, El Ansaric N, El Mansourid F, Belaabidia B. Fatal hypoglycaemia from IGF II hyperproduction as a complication of a mesenteric gastrointestinal stromal tumour. Arab J Gastroenterol. 2011; 12:171-172.

25. Yamamoto H, Kojima A, Nagata S, Tomita Y, Takahashi S, Oda Y. KIT-negative gastrointestinal stromal tumor of the abdominal soft tissue: a clinicopathologic and genetic study of 10 cases. Am J Surg Pathol. 2011; 35:1287-1295.

26. Barros A, Linhares E, Valadao M, Goncalves R, Vilhena B, Gil C, Ramos C. Extragastrointestinal stromal tumors (EGIST): a series of case reports. Hepatogastroenterology. 2011; 58:865-868.

27. Tsumuraya M, Kato H, Miyachi K, Sasaki K, Tsubaki M, Akimoto K, Sunagawa M. Comprehensive analysis of genes involved in the malignancy of gastrointestinal stromal tumors. Anticancer Res. 2010; 30:2705-2715.

28. Goncalves R, Linhares E, Albagli R, Valadao M, Vilhena B, Romano S, Ferreira CG. Occurrence of other tumors in patients with GIST. Surg Oncol. 2010; 19:e140-e143.

29. Woodward LM. Management of an enterocutaneous fistula in a patient with a gastrointestinal stromal tumor. J Wound Ostomy Continence Nurs. 2010; 37:314-317. 
30. Valero LA, Cascales SP, Prat CA, Rueda MJ, Gonzalez MJ, Garcia BE, Usero RS, Martinez MA, Moreno RJ. Mesenteric gastrointestinal stromal tumor. Rev Esp Enferm Dig. 2010; 102:218-219.

31. Velasco S, Milin S, Maurel C, Richer JP, Sylvain C, Hannequin J, Tasu JP. Scanographic features of gastrointestinal stromal tumors. Gastroenterol Clin Biol. 2008; 32:1001-1013.

32. Padilla D, Menendez P, Garcia M, Villarejo P, Cubo T, Gambi D, Pardo R, Martin J. [Immunohistochemical expression of epidermal growth factor and its prognostic value for gastrointestinal stromal tumors]. [Article in Spanish]. Rev Esp Enferm Dig. 2008; 100:752-757.

33. Gupta N, Mittal S, Lal N, Misra R, Kumar L, Bhalla S. A rare case of primary mesenteric gastrointestinal stromal tumor with metastasis to the cervix uteri. World J Surg Oncol. 2007; 5:137.

34. Fernandez SL, Alvarez GT, Sanz RA, Velayos JB, Aller De La Fuente R, Gonzalez HJ. [Gastrointestinal stromal tumors (GISTs): clinical aspects]. [Article in Spanish]. Rev Esp Enferm Dig. 2007; 99:19-24.

35. Puri T, Gunabushanam G, Malik M, Goyal S, Das AK, Julka PK, Rath GK. Mesenteric gastrointestinal stromal tumour presenting as intracranial space occupying lesion. World J Surg Oncol. 2006; 4:78.

36. Moschos J, Tzilves D, Paikos D, Tagarakis G, Pilpilidis I, Antonopoulos Z, Kadis S, Katsos I, Tarpagos A. Large mesenteric gastrointestinal stromal tumor in a patient with familial adenomatous polyposis syndrome. Wien Klin Wochenschr. 2006; 118:355-357.

37. Yasuda K, Adachi Y, Kitano S, Eto J, Miyakawa I, Kashima $\mathrm{K}$. Gastrointestinal stromal tumor with diffuse mesenteric metastases. Int Surg. 2005; 90:215-218.

38. Jaworski R, Jastrzebski T, Swierblewski M, Drucis K, Kobierska-Gulida G. Coexistence of hepatocellular carcinoma and gastrointestinal stromal tumor: a case report. World J Gastroenterol. 2006; 12:665-667.

39. Irving JA, Lerwill MF, Young RH. Gastrointestinal stromal tumors metastatic to the ovary: a report of five cases. Am J Surg Pathol. 2005; 29:920-926.

40. Basile A, Kettenbach J, Mundo E, Natoli A, Caloggero $\mathrm{S}$, Minciullo M, Garito A. Primitive mesenteric gastrointestinal stromal tumor with autonomic nerve/ ganglionic differentiation presenting as a huge mass with small synchronous nodules. Eur Radiol. 2006; 16:422-427.

41. Medeiros F, Corless CL, Duensing A, Hornick JL, Oliveira AM, Heinrich MC, Fletcher JA, Fletcher CD. KIT-negative gastrointestinal stromal tumors: proof of concept and therapeutic implications. Am J Surg Pathol. 2004; 28:889894.

42. Nakayama T, Hirose H, Isobe K, Shiraishi K, Nishiumi T, Mori S, Furuta Y, Kasahara M. Gastrointestinal stromal tumor of the rectal mesentery. J Gastroenterol. 2003; 38:186-189.
43. Levy AD, Remotti HE, Thompson WM, Sobin LH, Miettinen M. Gastrointestinal stromal tumors: radiologic features with pathologic correlation. Radiographics. 2003; 23:283-304, 456, 532.

44. Gorospe L, Simon MJ, Lima F, Esteban I, Madrid C, Hitos E. Primary mesenteric tumor with phenotypical features of gastrointestinal stromal tumors. Eur Radiol. 2002; 12 Suppl 3:S82-S85

45. Goukassian ID, Kussman SR, Toribio Y, Rosen JE. Secondary recurrent multiple EGIST of the mesentary: A case report and review of the literature. Int J Surg Case Rep. 2012; 3:463-466.

46. Yamamoto H, Oda Y, Kawaguchi K, Nakamura N, Takahira T, Tamiya S, Saito T, Oshiro Y, Ohta M, Yao T, Tsuneyoshi M. c-kit and PDGFRA mutations in extragastrointestinal stromal tumor (gastrointestinal stromal tumor of the soft tissue). Am J Surg Pathol. 2004; 28:479-488.

47. Iqbal N, Sharma A, Iqbal N. Clinicopathological and treatment analysis of 13 extragastrointestinal stromal tumors of mesentery and retroperitoneum. Ann Gastroenterol. 2015; 28:105-108.

48. Zhu J, Yang Z, Tang G, Wang Z. Extragastrointestinal stromal tumors: Computed tomography and magnetic resonance imaging findings. Oncol Lett. 2015; 9:201-208.

49. Kim KH, Nelson SD, Kim DH, Choi KU, Kim SJ, Min KW, Jang KS, Paik SS, Oh YH, Chae SW, Sohn JH, Kim HJ, Cho YK, et al. Diagnostic relevance of overexpressions of PKC-theta and DOG-1 and KIT/PDGFRA gene mutations in extragastrointestinal stromal tumors: a Korean six-centers study of 28 cases. Anticancer Res. 2012; 32:923-937.

50. Li ZY, Huan XQ, Liang XJ, Li ZS, Tan AZ. [Clinicopathological and immunohistochemical study of extra-gastrointestinal stromal tumors arising from the omentum and mesentery]. [Article in Chinese]. Zhonghua Bing Li Xue Za Zhi. 2005; 34:11-14.

51. Hou YY, Sun MH, Wei YK, Tan YS, Lu XY, Wang J, Zhu $\mathrm{XZ}$, Zheng AH. [Clinicopathological, immunohistochemical and molecular genetic study of intra-abdomen extragastrointestinal stromal tumors]. [Article in Chinese]. Zhonghua Bing Li Xue Za Zhi. 2003; 32:422-426.

52. Miettinen M, Monihan JM, Sarlomo-Rikala M, Kovatich AJ, Carr NJ, Emory TS, Sobin LH. Gastrointestinal stromal tumors/smooth muscle tumors (GISTs) primary in the omentum and mesentery: clinicopathologic and immunohistochemical study of 26 cases. Am J Surg Pathol. 1999; 23:1109-1118.

53. Joensuu H. Risk stratification of patients diagnosed with gastrointestinal stromal tumor. Hum Pathol. 2008; 39:14111419. 